\title{
Purification and Properties of a New Enzyme, Glutathione Oxidase from Penicillium sp. K-6-5
}

\author{
Hitoshi KusaKabe, Akira KuninaKa and Hiroshi Yoshino \\ Research Laboratories, Yamasa Shoyu Co. Ltd., \\ Choshi, Chiba 288, Japan
}

Received January 11, 1982

\begin{abstract}
A new flavoprotein enzyme, GSH oxidase, was found in the aqueous extract of a wheat bran culture of Penicillium sp. K-6-5. The oxidase is also produced extra and intracellularly in the liquid culture, although the production is much lower than that in the wheat bran culture.

The enzyme has been purified to homogeneity. It shows absorption maxima at 270,350 and $444 \mathrm{~nm}$ and a shoulder around $465 \mathrm{~nm}$ and contains 2 mol of FAD per mol of enzyme. The enzyme has a molecular weight of approximately 95,000 and consists of two subunits identical in molecular weight (about 47,000). Balance studies show that $2 \mathrm{~mol}$ of GSH are converted to $1 \mathrm{~mol}$ of GSSG and hydrogen peroxide with the consumption of $1 \mathrm{~mol}$ of oxygen. In addition to GSH, several sulfhydryl compounds are oxidized by the enzyme to a lesser extent. The Michaelis constants are as follows: $0.69 \mathrm{~mm}$ for $\mathrm{GSH}, 3.6 \mathrm{~mm}$ for L-cysteine and $6.7 \mathrm{~mm}$ for dithiothreitol at $\mathrm{pH} 7.4$. The oxidase scarcely acts on reduced RNase A in contrast to the known sulfhydryl oxidases. The isoelectric point and the optimal $\mathrm{pH}$ are 4.2 and 7.4, respectively. The enzyme activity is completely inhibited by addition of $1 \mathrm{~mm} \mathrm{ZnSO}_{4}$.
\end{abstract}

Sulfhydryl oxidases have been isolated from bovine milk, ${ }^{1)}$ rat seminal vesicle secretion ${ }^{2)}$ and rat skin. ${ }^{3}$ These enzymes catalyze the oxidation of GSH and several other low molecular weight sulfhydryl compounds with the formation of the corresponding disulfides and hydrogen peroxide as follows: $2 \mathrm{RSH}+\mathrm{O}_{2}$ $\rightarrow$ RSSR $+\mathrm{H}_{2} \mathrm{O}_{2}$, but show no specificity for GSH. They also effectively act on the cysteine residues of reduced RNase A. Among these oxidases, only the one from rat seminal vesicle secretion is a flavoprotein; its prosthetic group is FAD. The bovine milk oxidase contains iron as a cofactor, and the enzyme from rat skin does not have any cofactor.

GSH oxidase activity was observed in mammalian tissues by several investigators. ${ }^{4 \sim 6)}$ However, a recent study has provided evidence that the oxygen dependent conversion of GSH to GSSG is ascribable to the $\gamma$-glutamyl transpeptidase mediated formation of cysteinylglycine and to the subsequent nonenzymatic oxidation. ${ }^{7)}$ Therefore, a flavoprotein oxidase which prefers GSH to other sulfhydryl compounds as a substrate has not only been not demonstrated in microorganisms but also not in other living substances.

In the course of a search for oxygen consuming enzymes produced in wheat bran cultures of molds, we found a new flavoprotein sulfhydryl oxidase having high specificity and affinity for GSH. We here report its purification and enzymological properties.

\section{MATERIALS AND METHODS}

Materials. GSH, GSSG, catalase (bovine liver), Damino acid oxidase (hog kidney), RNase A (bovine pancreas) and GSH reductase (yeast) were purchased from Sigma Chemical Co., St. Louis, USA, FAD and FMN were prepared by Yamasa Shoyu Co., Ltd., Choshi, Japan. Other chemicals were of analytical grade available from commercial sources.

Microorganisms. A fungal strain, K-6-5, was isolated

Abbreviations: GSH, glutathione; GSSG, oxidized glutathione; FAD, flavine adenine dinucleotide, FMN, flavine mononucleotide; SDS, sodium dodecyl sulfate; DTNB, 5,5'-dithiobis-2-nitrobenzoic acid. 
from soil in Choshi. The mold grown on a medium consisting of $2 \%$ glucose, $2 \%$ malt extract, $0.1 \%$ peptone and $2.5 \%$ agar, $\mathrm{pH} 6.0$, had a penicillus with metulae which is characteristic of the genus Penicillium. Further identification of the mold is now in progress. Other molds tested for the screening were also isolated from soil samples.

Wheat bran culture. Molds were grown in $500 \mathrm{ml}$ flasks, each of which contained $20 \mathrm{~g}$ of wheat bran supplemented with $14 \mathrm{ml}$ of water, at $28^{\circ} \mathrm{C}$ for 7 days unless otherwise stated. The entire culture was soaked in $150 \mathrm{ml}$ of water at $28^{\circ} \mathrm{C}$ for $1 \mathrm{hr}$ with gentle shaking and then squeezed through a cloth. The extract was centrifuged to remove spores and mycelia, after which it was stored at $-20^{\circ} \mathrm{C}$ until use.

Screening of oxygen consuming enzymes. The wheat bran culture extract $(40 \mathrm{ml})$ was brought to $95 \%$ saturation with ammonium sulfate. The precipitate collected by centrifugation was dissolved in $5 \mathrm{ml}$ of $0.02 \mathrm{M}$ potassium phosphate buffer, $\mathrm{pH}$ 7.4. The enzyme solution was dialyzed overnight against the same buffer. The insoluble materials formed during dialysis were removed by centrifugation, and the volume was adjusted to $10 \mathrm{ml}$ with the buffer. The oxygen consuming activity of the ammonium sulfate precipitated-preparation against the arbitrary amino acids or sugars was examined in $0.2 \mathrm{M}$ potassium phosphate buffer, $\mathrm{pH} 7.4$, with a Hansatek oxygen electrode. The final concentration of each compound contained in the substrate mixtures was $5 \mathrm{~mm}$.

Enzyme assay. GSH oxidase was assayed by monitoring the decrease in oxygen concentration with a Hansatek oxygen electrode. The standard reaction mixture consisted of $10 \mu \mathrm{mol}$ of $\mathrm{GSH}, 100 \mu \mathrm{mol}$ of potassium phosphate buffer, $\mathrm{pH}$ 7.4, 350 units of catalase, and the enzyme in a final volume of $1.1 \mathrm{ml}$. The reaction was carried out at $30^{\circ} \mathrm{C}$ with stirring in the electrode vessel. The initial concentration of oxygen in the assay solution was 0.23 $\mu \mathrm{mol} / \mathrm{ml}$ under the above conditions. One unit of enzyme was defined as the amount of enzyme that consumes $0.5 \mu \mathrm{mol}$ of oxygen per min under the standard assay conditions.

Protein determination. Protein was determined by the method of Lowry et $a l^{8)}$ with bovine serum albumin as the standard. The protein elution patterns on column chromatography were estimated by $280 \mathrm{~nm}$ absorption.

Purification of GSH oxidase. The aqueous extract of a wheat bran culture of Penicillium sp. K-6-5 (16 liters) was brought to $65 \%$ saturation with ammonium sulfate, and the precipitate was discarded after centrifugation. Ammonium sulfate was added to the supernatant liquid to $95 \%$ saturation. The resulting precipitate was collected by centrifugation and dissolved in 1 liter of $0.02 \mathrm{M}$ potassium phosphate buffer, $\mathrm{pH}$ 7.4. The enzyme solution was dialyzed overnight against the same buffer. The insoluble materials formed during dialysis were removed by centrifugation. The dialyzed enzyme solution (1.7 liters) was adjusted to about $\mathrm{pH} 5.0$ by addition of $150 \mathrm{ml}$ of $1 \mathrm{M}$ acetate buffer, $\mathrm{pH}$ 5.0. Forty grams of charcoal was added to the enzyme solution, and the mixture was heated at $58^{\circ} \mathrm{C}$ for $30 \mathrm{~min}$ with occasional stirring. After the charcoal was removed by centrifugation, ammonium sulfate was added to $95 \%$ saturation. The precipitate formed was collected and dissolved in $200 \mathrm{ml}$ of $0.02 \mathrm{M}$ potassium

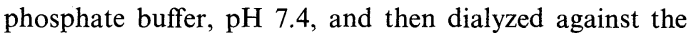
same buffer. The dialyzed solution $(280 \mathrm{ml})$ was applied to a DEAE-cellulose column $(6.5 \times 60 \mathrm{~cm})$ equilibrated with $0.02 \mathrm{M}$ potassium phosphate buffer, $\mathrm{pH}$ 7.4. After the column was washed with 3 liters of the buffer, the enzyme was eluted with a linear gradient of 0 to $0.4 \mathrm{M} \mathrm{NaCl}$. Active fractions collected were concentrated by addition of ammonium sulfate $(95 \%$ saturation), and then dialyzed against the buffer. The dialyzed enzyme $(4 \mathrm{ml})$ was applied to a Sephadex G-200 column $(3.5 \times 100 \mathrm{~cm})$ equilibrated with $0.02 \mathrm{M}$ potassium phosphate buffer, $\mathrm{pH}$ 7.4, and then eluted with the buffer at a flow rate of $25 \mathrm{ml}$ per hr. The active fractions were collected and concentrated by addition of ammonium sulfate. The precipitate was dissolved in a small volume of $0.02 \mathrm{M}$ Tris- $\mathrm{HCl}$ buffer, $\mathrm{pH} 8.4$, and dialyzed against the same buffer. The enzyme solution was placed on a DEAESephadex A-50 column $(1.5 \times 6 \mathrm{~cm})$ equilibrated with $0.02 \mathrm{M}$ Tris- $\mathrm{HCl}$ buffer, $\mathrm{pH} 8.4$, containing $0.05 \mathrm{M} \mathrm{NaCl}$. The column was washed with $30 \mathrm{ml}$ of the same buffer, and then with $50 \mathrm{ml}$ of the buffer containing $0.15 \mathrm{M}$ $\mathrm{NaCl}$. The enzyme was eluted with the buffer containing $0.2 \mathrm{M} \mathrm{NaCl}$ at a flow rate of $7 \mathrm{ml}$ per hr. The active fractions were collected and concentrated with a membrane concentrator. The purified yellow enzyme was dialyzed against $0.02 \mathrm{M}$ potassium phosphate buffer, $\mathrm{pH}$ 7.4 .

Determination of molecular weight. The molecular weight was determined by gel filtration on a column $(1.5 \times 100 \mathrm{~cm})$ of Sephadex G-200 according to the method of Andrews. ${ }^{9)}$ Elution was carried out with $0.02 \mathrm{M}$ potassium phosphate buffer, $\mathrm{pH}$ 7.4. A calibration curve was made with standard proteins: L-lysine $\alpha$-oxidase (mol. wt. 112,000), bovine serum albumin (mol. wt. 67,000), $\alpha$-chymotrypsinogen (mol. wt. 25,000) and cytochrome $c$ (mol. wt. 12,400). $V_{0}$ was determined with blue dextran 2,000.

The molecular weight of the subunit was estimated by SDS-gel electrophoresis according to the method of Weber and Osborn. ${ }^{10)}$ The enzyme was dialyzed against 100

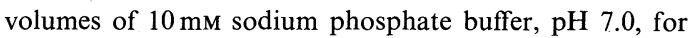
$24 \mathrm{hr}$, and then denatured by treatment with $1 \%$ SDS solution containing $1 \%$ 2-mercaptoethanol at $100^{\circ} \mathrm{C}$ for $5 \mathrm{~min}$. Standard proteins: glutamate dehydrogenase (mol. wt. 53,000), egg albumin (mol. wt. 43,000), $\alpha$-chymotryp- 
sinogen (mol. wt. 25,000), and cytochrome $c$ (mol. wt. $12,400)$ were treated in the same way.

High-performance liquid chromatography analysis. Enzymatic product analysis was performed with a Shimadzu LA-3 high-performance liquid chromatograph (HPLC). The conditions: column, JASCOSIL SC-02 $(4.5 \times 250 \mathrm{~mm})$; solvent, $0.02 \mathrm{M} \mathrm{KH}_{2} \mathrm{PO}_{4}(\mathrm{pH} 2.5)$; temperature, $5^{\circ} \mathrm{C}$; flow rate, $1 \mathrm{ml} / \mathrm{min}$.

Reductive denaturation and renaturation of $R$ Nase $A$. RNase A was reduced with 2-mercaptoethanol in the presence of $8 \mathrm{M}$ urea according to the method of Haber and Anfinsen. ${ }^{11)}$ Bovine pancreatic RNase A (34 mg) was dissolved in $2 \mathrm{ml}$ of $0.15 \mathrm{M}$ potassium phosphate buffer, $\mathrm{pH}$ 7.4 , containing $8 \mathrm{M}$ urea, then $0.1 \mathrm{ml}$ of 2 -mercaptoethanol was added to the solution. The test tube containing the solution was flushed with nitrogen, sealed with parafilm and allowed to stand at room temperature for $5 \mathrm{hr}$. The reduced enzyme solution was applied to a Sephadex G-25 column $(2.5 \times 80 \mathrm{~cm})$ equilibrated with $0.1 \mathrm{M}$ acetate buffer, $\mathrm{pH} 5.1$, and eluted with the buffer. The $\mathrm{pH}$ of the reduced enzyme was adjusted to 7.4 with saturated Tris base before the renaturation experiment.

For renaturation of the reduced $\mathrm{RNase} A$, the reaction mixture contained $1 \mathrm{ml}$ of the reduced RNase $\mathrm{A}(0.32 \mathrm{mg}$ / $\mathrm{ml}$ ), $2 \mathrm{ml}$ of $0.1 \mathrm{M}$ potassium phosphate buffer, $\mathrm{pH} 7.4$, and $10 \mu \mathrm{l}$ of $\mathrm{GSH}$ oxidase $(200 \mathrm{units} / \mathrm{ml})$. The control was identical except for the substitution of $10 \mu \mathrm{l}$ of $0.02 \mathrm{M}$ potassium phosphate buffer, $\mathrm{pH} 7.4$, for GSH oxidase. The reaction was carried out at $37^{\circ} \mathrm{C}$, and aliquots were removed at various times for determination of the sulfhydryl concentration using DTNB ${ }^{12)}$ and for the assay of RNase activity with yeast RNA as substrate at $\mathrm{pH}$ 5.3. ${ }^{13}$ )

Isoelectric focusing. Isoelectric focusing of the enzyme in polyacrylamide gel was carried out according to the method of Righetti and Drysdale ${ }^{14)}$ with carrier ampholytes in the $\mathrm{pH}$ range of 3.5 to 10.0 at $3^{\circ} \mathrm{C}$. After electrophoresis, the sliced gels were immersed in water in order to measure the $\mathrm{pH}$ and the enzyme activity.

\section{RESULTS}

\section{Occurrence of GSH oxidase in the aqueous} extract of a wheat bran culture of Penicillium sp. $K-6-5$

In the course of a search for extracellular oxidases produced in wheat bran cultures of molds, the ammonium sulfate precipitatedpreparation from Penicillium sp. K-6-5 was found to exhibit oxygen consuming activity against the amino acids mixture. The nondialyzable activity was lost completely on treatment at $75^{\circ} \mathrm{C}$ for $30 \mathrm{~min}$. Among the 23 kinds of amino acids contained in the substrate mixture, L-cysteine was exclusively oxidized by the preparation. The crude enzyme also oxidized GSH more rapidly than L-cysteine as

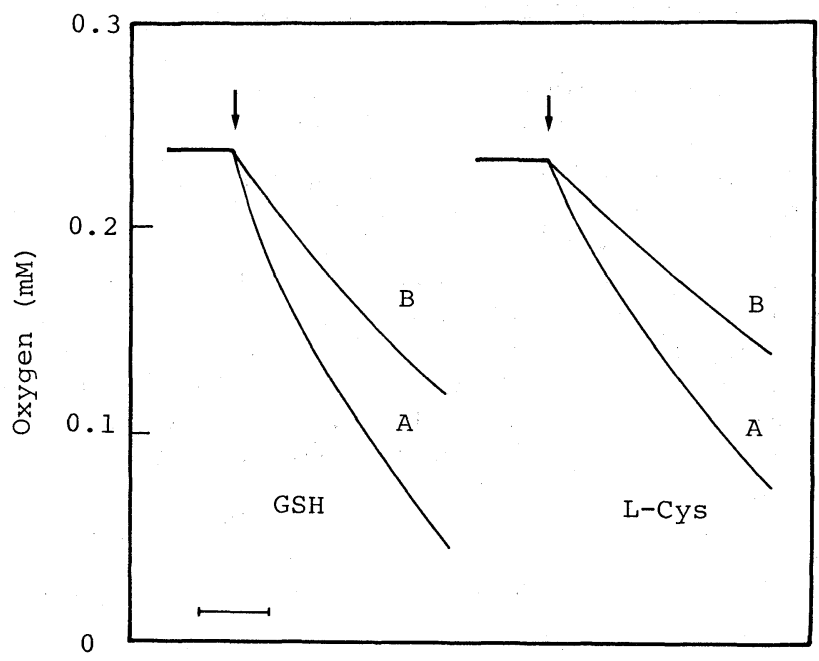

FIg. 1. Oxygen Consumption During the Reaction of the Crude Enzyme from Penicillium sp. K-6-5 with GSH or L-Cysteine.

The oxygen consumption was followed with an oxygen electrode at $30^{\circ} \mathrm{C}$. The electrode cuvette contained 100

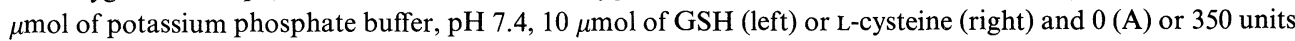
(B) of catalase in a total volume of $1.0 \mathrm{ml}$. The reaction was initiated by injection of $20 \mu \mathrm{l}$ of the ammonium sulfate precipitated-preparation from Penicillium sp. K-6-5 as indicated by an arrow. The bar represents $1 \mathrm{~min}$. 
shown in Fig. 1. This figure also shows that the initial rate of oxygen consumption was reduced to about one half by the addition of catalase. This indicates that the oxygen consumption was accompanied by formation of an equimolar amount of hydrogen peroxide. The formation of the corresponding disulfides from GSH and L-cysteine by the preparation was confirmed by thin layer chromatography. These results show that a certain sulfhydryl oxidase was present in the crude enzyme preparation.

Time-courses of the enzyme production in wheat bran cultures

Penicillium sp. K-6-5 was cultured on wheat bran at $20^{\circ} \mathrm{C}$ and $28^{\circ} \mathrm{C}$. Figure 2 shows that the production at $20^{\circ} \mathrm{C}$ was much higher than that at $28^{\circ} \mathrm{C}$. Maximum production of the enzyme was observed after 5 and 9 days incubation at $28^{\circ} \mathrm{C}$ and $20^{\circ} \mathrm{C}$, respectively.

\section{Production of the enzyme in liquid cultures}

Extra and intracellular production of the enzyme in liquid cultures of the mold was examined with 7 different media as shown in Table I. A relatively small but appreciable amount of the enzyme was formed in the cells, and also produced extracellularly in medium $\mathrm{C}$ and $\mathrm{G}$. The extracellular production was approximately 100 times lower than that in the wheat bran culture. This result demonstrates that a wheat bran culture of the mold is suitable for isolation of the enzyme.

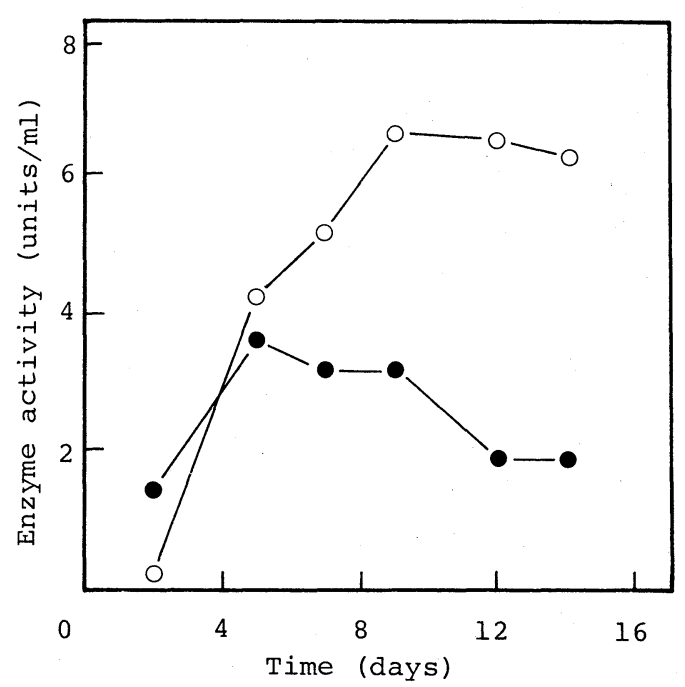

FIG. 2. Time-courses of GSH Oxidase Production by Penicillium sp. K-6-5.

The mold was grown on wheat bran at $20^{\circ} \mathrm{C}$ and $28^{\circ} \mathrm{C}$. O, $20^{\circ} \mathrm{C} ; 0,28^{\circ} \mathrm{C}$.

\section{TABle I. Production of GSH Oxidase in LiQuid Cultures of Penicillium sp. K-6-5}

Penicillium sp. K-6-5 was cultured at $28^{\circ} \mathrm{C}$ for 5 days with shaking in the following media: (A) $4 \%$ glucose, $2 \%$ asparagine, $0.05 \% \mathrm{~K}_{2} \mathrm{HPO}_{4}, 0.0025 \% \mathrm{MgSO}_{4} \cdot 7 \mathrm{H}_{2} \mathrm{O}$ and $0.5 \mathrm{mg} / \mathrm{ml}$ of thiamin chloride, (B) $3 \%$ saccharose, $0.2 \% \mathrm{NaNO}_{3}, 0.1 \% \mathrm{~K}_{2} \mathrm{HPO}_{4}, 0.05 \% \mathrm{MgSO}_{4} \cdot 7 \mathrm{H}_{2} \mathrm{O}, 0.05 \% \mathrm{KCl}$ and $0.001 \% \mathrm{FeSO}_{4} \cdot 7 \mathrm{H}_{2} \mathrm{O}$, (C) $5 \%$ glucose, $0.5 \%$ peptone, $0.05 \% \mathrm{~K}_{2} \mathrm{HPO}_{4}, 0.05 \% \mathrm{KH}_{2} \mathrm{PO}_{4}, 0.04 \% \mathrm{MgSO}_{4} \cdot 7 \mathrm{H}_{2} \mathrm{O}$ and $0.04 \% \mathrm{CaCl}_{2} \cdot 2 \mathrm{H}_{2} \mathrm{O}$, (D) $5 \%$ glucose, $0.5 \%$ peptone, $0.25 \%$ meat extract, $0.05 \% \mathrm{MgSO}_{4} \cdot 7 \mathrm{H}_{2} \mathrm{O}, 0.05 \% \mathrm{KCl}$ and $0.001 \% \mathrm{FeSO}_{4} \cdot 7 \mathrm{H}_{2} \mathrm{O},(\mathrm{E})$ $4 \%$ maltose and $1 \%$ peptone, (F) $1.5 \%$ glucose, $1 \%$ glycerol, $1 \%$ malt extract, $0.5 \%$ casamino acids and $0.1 \%$ yeast extract, and $(\mathrm{G}) 1.5 \%$ soluble starch, $0.4 \%$ yeast extract, $0.1 \% \mathrm{~K}_{2} \mathrm{HPO}_{4}$ and $0.05 \% \mathrm{MgSO}_{4} \cdot 7 \mathrm{H}_{2} \mathrm{O}$. After separation of the mycelia from the culture broth, $1 \mathrm{~g}$ of wet mycelia was disrupted with $10 \mathrm{~g}$ of quartz sand in order to extract the enzyme with $10 \mathrm{ml}$ of $0.02 \mathrm{M}$ potassium phosphate buffer, $\mathrm{pH} 7.4$.

\begin{tabular}{ccc}
\hline & \multicolumn{2}{c}{ Enzyme activity (units/100 ml medium) } \\
\cline { 2 - 3 } Medium & Culture broth & Mycelia extract \\
\hline A & 0 & 0 \\
B & 0 & 0 \\
C & 70 & 128 \\
D & 0 & 277 \\
E & 0 & 0 \\
F & 0 & 446 \\
G & 58 & 72 \\
\hline
\end{tabular}


Table II. Purification of the EnZyme

\begin{tabular}{lrcrr}
\hline \multicolumn{1}{c}{ Step } & $\begin{array}{c}\text { Total } \\
\text { protein } \\
(\mathrm{mg})\end{array}$ & $\begin{array}{c}\text { Total } \\
\text { activity } \\
\text { (units) }\end{array}$ & $\begin{array}{c}\text { Specific } \\
\text { activity } \\
\text { (units/mg) }\end{array}$ & $\begin{array}{c}\text { Yield } \\
(\%)\end{array}$ \\
\hline Culture extract & 59,700 & 136,000 & 2.3 & 100.0 \\
Ammonium sulfate & 15,300 & 113,000 & 7.4 & 83.1 \\
Heat treatment & 6,040 & 95,100 & 15.7 & 69.9 \\
DEAE-Cellulose & 197 & 31,200 & 158.4 & 22.9 \\
Sephadex G-200 & 66 & 20,600 & 312.1 & 15.1 \\
DEAE-Sephadex A-50 & 21 & 11,400 & 543.0 & 8.4 \\
\hline
\end{tabular}

\section{Purification of the enzyme}

The GSH oxidizing enzyme was purified from the aqueous extract of Penicillium sp. K6-5 grown on wheat bran by procedures involving fractionation with ammonium sulfate, heat treatment, column chromatographies on DEAE-cellulose and DEAE-Sephadex A-50 and gel filtration on Sephadex G-200 as described above. The overall purification was 236-fold with a yield of $8.4 \%$ as shown in Table II. A yellow colored protein with a specific activity of 543 units per mg protein was obtained. The purified enzyme was proved to be homogeneous by disc gel electrophoresis. The section of the unstained gel corresponding to the single protein band was cut out and crushed in a small volume of $0.02 \mathrm{M}$ potassium phosphate buffer, $\mathrm{pH}$ 7.4. The protein was extracted at $3^{\circ} \mathrm{C}$ for $2 \mathrm{hr}$ and it contained the GSH oxidase activity. Homogeneity of the enzyme was also demonstrated by SDS-disc gel electrophoresis; there was only a single band of stained protein (Fig. 3).

\section{Absorption and fluorescence spectra}

The enzyme showed a typical absorption spectrum of a flavoprotein having maxima at 270,350 and 444 and a shoulder at $465 \mathrm{~nm}$ with molar absorption coefficients of 146,500 , 13,900, 13,700 and 11,800, respectively (Fig. 4).

The fluorescence spectrum of the enzyme was measured at $\mathrm{pH} 7.4$ and 3.0. When fluorescence emission was monitored at $530 \mathrm{~nm}$ in $0.2 \mathrm{M}$ potassium phosphate buffer, $\mathrm{pH} 7.4$, the

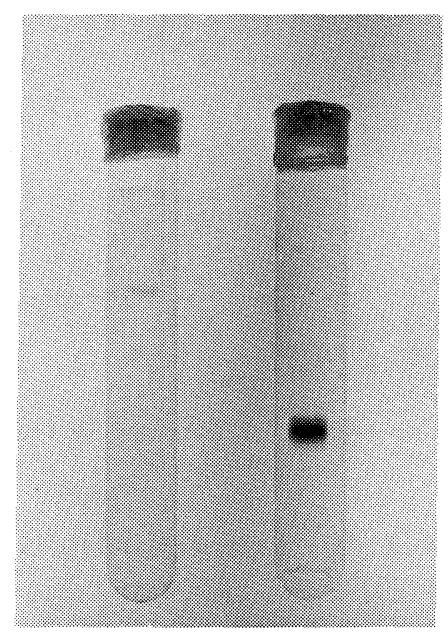

FIG. 3. Polyacrylamide Gel-electrophoreses of GSH Oxidase.

The purified enzyme was applied to polyacrylamide gel with (left) or without SDS-treatment (right). The amounts of the protein used for disc and SDS-disc electrophoreses were 40 and $5 \mu \mathrm{g}$, respectively.

excitation spectrum exhibited maxima at 370 and $450 \mathrm{~nm}$. No spectral change occurred when the $\mathrm{pH}$ was shifted to 3.0. However, the fluorescence intensity increased markedly during incubation of the enzyme in $0.2 \mathrm{M}$ acetate buffer, $\mathrm{pH} 3.0$, at $45^{\circ} \mathrm{C}$ for $5 \mathrm{~min}$. The spectrum was identical with that of FAD. This suggests that the prosthetic flavin group is released from the enzyme protein under the acidic conditions thus enhancing the fluorescence yeild.

\section{Molecular weight and subunit structure}

The molecular weight of the enzyme was 


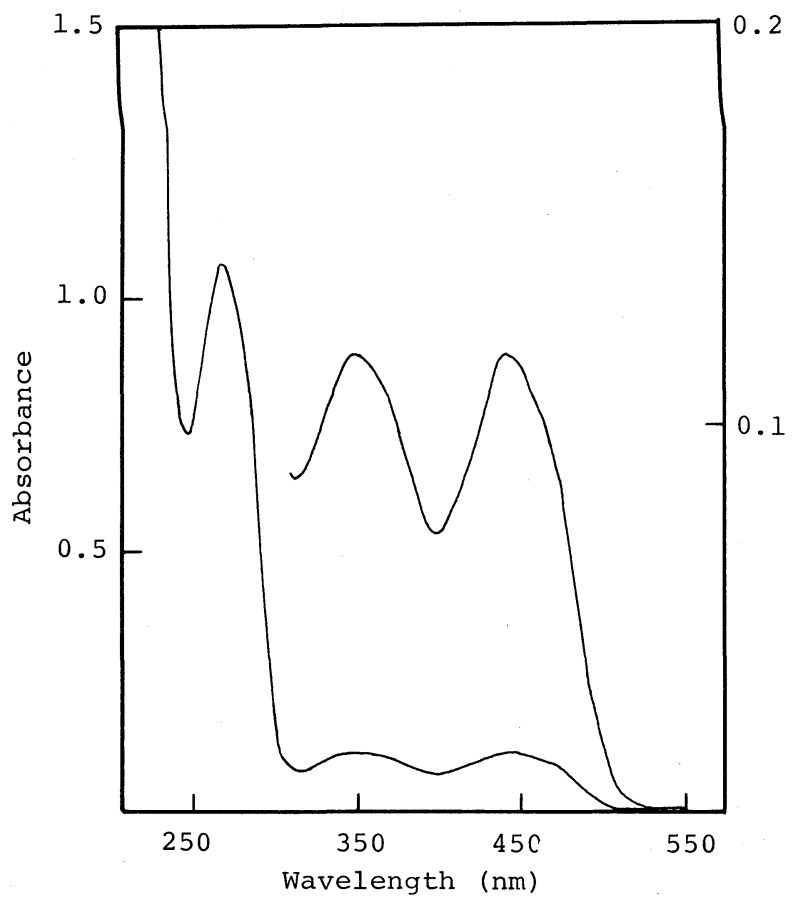

FIG. 4. Absorption Spectrum of GSH Oxidase $(0.6 \mathrm{mg} / \mathrm{ml})$ in $0.02 \mathrm{~m}$ Potassium Phosphate Buffer, $\mathrm{pH}$ 7.4.

estimated to be approximately 95,000 by Sephadex G-200 gel filtration. The subunit structure was analyzed by SDS-gel electrophoresis in the presence of $1 \%$ SDS. The molecular weight of the subunit was estimated to be 47,000 from a semilogarithmic plot of molecular weight against mobility. These results show that the enzyme is composed of two subunits of identical molecular weight.

\section{Prosthetic group}

The absorption and fluorescence spectra of the enzyme indicate that the flavin nucleotide is a prosthetic group. The enzyme was kept in boiling water for $5 \mathrm{~min}$ and then was centrifuged to remove denatured protein. The yellow supernatant solution was examined by thin layer chromatography (Silica gel G, Merck, Germany) with a solvent system of tert-amylalcohol-formic acid-water $(3: 1: 1)$. A single yellow spot $(R f=0.08)$ which corresponded to FAD was observed, and the $R f$ value of FMN was 0.19 under these conditions. In addition, the supernatant solution activated apo-D-amino acid oxidase; the restored enzyme activity was confirmed with an oxygen electrode. Thus, the flavin moiety was identified as FAD. To measure the FAD content, $0.1 \mathrm{ml}$ of $25 \%$ trichloroacetic acid was added to $0.5 \mathrm{ml}$ of the enzyme solution containing $0.27 \mathrm{mg}$ of protein $(2.8 \mathrm{nmol})$. Then the mixture was centrifuged. After the supernatant solution was neutralized with $0.5 \mathrm{M} \mathrm{K}_{2} \mathrm{HPO}_{4}$, it was brought to $9.0 \mathrm{ml}$ with water. The amount of FAD was determined fluorometrically to be $4.5 \mathrm{nmol}$. This result indicates that $2 \mathrm{~mol}$ of FAD were bound per mol of the enzyme protein.

\section{Reaction product}

After aerobic incubation of GSH with the enzyme in the presence of catalase at $37^{\circ} \mathrm{C}$ for $1 \mathrm{hr}$, the reaction product was analyzed by high-performance liquid chromatography (Fig. 5). The reaction product was eluted at the same retention time as the authentic GSSG as shown in Fig. 5-b). In addition, the peak corresponding to GSH appeared after incu- 


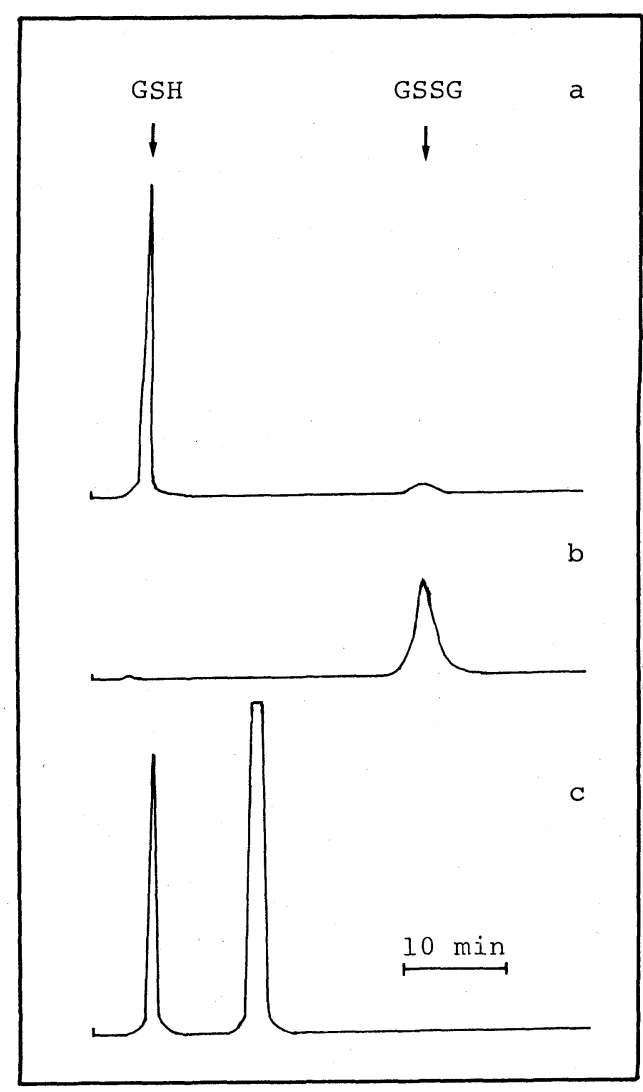

FIG. 5. High-performance Liquid Chromatography for Identification of the Reaction Product from GSH.

The reaction mixture contained $5 \mu \mathrm{mol}$ of GSH, $100 \mu \mathrm{mol}$ of potassium phosphate buffer, $\mathrm{pH} 7.4,100$ units of catalase and 0.4 units of the enzyme. At 0 time (a) and after $1 \mathrm{hr}$ incubation at $37^{\circ} \mathrm{C}$ (b), a $5 \mu \mathrm{l}$ aliquot was analyzed by HPLC. For reformation of GSH from the reaction product, $0.2 \mathrm{ml}$ of the reaction mixture was heated at $100^{\circ} \mathrm{C}$ for $3 \mathrm{~min}$ to inactivate the oxidase and mixed with $0.1 \mathrm{ml}$ of GSH reductase $(0.5$ units $/ \mathrm{ml})$ and $0.1 \mathrm{ml}$ of NADPH $(13 \mu \mathrm{mol} / \mathrm{ml})$. After incubation at $37^{\circ} \mathrm{C}$ for $1 \mathrm{hr}$, a $10 \mu \mathrm{l}$ aliquot was analyzed by HPLC (c).

bation of the reaction product with $\mathrm{GSH}$ reductase in the presence of NADPH at $37^{\circ} \mathrm{C}$ for $1 \mathrm{hr}$ (Fig. 5-c). The amount of GSH reformed from the product GSSG was approximately equimolar with that of GSH consumed on the basis of peak area.

The reaction product from L-cysteine was also examined. After aerobic incubation of $\mathrm{L}_{\mathrm{L}}$ cysteine with an excess amount of the enzyme in the presence of catalase in $0.05 \mathrm{M}$ potassium phosphate buffer, $\mathrm{pH} 7.4$, at $37^{\circ} \mathrm{C}$ for $6 \mathrm{hr}$, the white precipitate formed was collected and washed with cold water. The following result was obtained on elemental analysis of the powder:

$$
\mathrm{C}_{6} \mathrm{H}_{12} \mathrm{~N}_{2} \mathrm{O}_{4} \mathrm{~S}_{2}
$$

Calculated: Cystine

C 29.99, H 5.03, N 11.66

\section{Found : Product \\ C 29.68, H 4.83, N 11.84}

The IR spectrum of the reaction product with a $\mathrm{KBr}$ pellet was identical with that of the authentic cystine. From $1 \mathrm{mmol}$ of L-cysteine, $0.47 \mathrm{mmol}$ of cystine was obtained.

\section{Stoichiometry of the reaction}

The stoichiometry of the enzymatic oxidation of GSH was investigated (Table III). The ratio of the amount of GSH consumed to those of oxygen consumed and GSSG and hydrogen peroxide formed was almost $2: 1$ : $1: 1$ in the absence of catalase. The expected ratio of GSH consumed to oxygen consumed and GSSG formed was obtained in the presence of catalase. The initial rate of oxygen consumption with catalase was exactly one half of that without catalase when it was followed with an oxygen electrode.

\section{Substrate specificity}

The ability of the enzyme to catalyze oxidation of various sulfhydryl compounds was investigated as shown in Table IV. GSH was the substrate most efficiently oxidized. Dithiothreitol, the preferred substrate for the sulfhydryl oxidases so far studied, was not a good one. $N$-Acetyl-L-cysteine, L-cysteine methylester, cysteamine, thiophenol, 2mercaptoethanol and D-cysteine were oxidized to a lesser extent, but D, L-homocysteine was inert. The oxidase showed a high specificity for GSH at $\mathrm{pH} 5.0$ though the relative activity at this $\mathrm{pH}$ was about $50 \%$ of that at the optimal $\mathrm{pH}$.

In order to determine whether the oxidase acts on cysteine residues in protein to form disulfide bridges in it, we prepared fully re- 
TABLE III. Stoichiometry OF Oxidation OF GSH IN THE Presence or Absence of Catalase

Oxygen uptake was measured with an oxygen electrode. The vessel contained $0.25 \mu \mathrm{mol}$ of GSH, $100 \mu \mathrm{mol}$ of potassium phosphate buffer, $\mathrm{pH} 7.4,0$ or 100 units of catalase, and 0.13 units of the enzyme in a total volume of $1.0 \mathrm{ml}$. After incubation at $30^{\circ} \mathrm{C}$ for $20 \mathrm{~min}$, the reaction was stopped by addition of $1 \mathrm{ml}$ of $0.4 \mathrm{~N} \mathrm{HCl}$. GSH was determined with DTNB by the method of Ellman. ${ }^{12)}$ GSSG was determined fluorometrically with $o$ phthalaldehyde at $\mathrm{pH} 12$ by the method of Hissin and Hilf. ${ }^{15)}$ Hydrogen peroxide was measured with the 4aminoantipyrine-phenol-peroxidase system.

\begin{tabular}{ccccc}
\hline $\begin{array}{c}\text { Catalase } \\
(\text { units } / \mathrm{ml})\end{array}$ & $\begin{array}{c}\text { GSH Consumed } \\
(\mu \mathrm{mol})\end{array}$ & $\begin{array}{c}\mathrm{O}_{2} \text { Consumed } \\
(\mu \mathrm{mol})\end{array}$ & $\begin{array}{c}\text { GSSG Formed } \\
(\mu \mathrm{mol})\end{array}$ & $\begin{array}{c}\mathrm{H}_{2} \mathrm{O}_{2} \text { Formed } \\
(\mu \mathrm{mol})\end{array}$ \\
\hline 0 & 0.225 & 0.084 & 0.094 & 0.089 \\
100 & 0.236 & 0.051 & 0.124 & \\
\hline
\end{tabular}

Table IV. Substrate SPecificity OF THE ENZYME

\begin{tabular}{lcc}
\hline \multirow{2}{*}{ Substrate (5 mM) } & \multicolumn{2}{c}{ Rel. activity (\%) } \\
\cline { 2 - 3 } & pH 5.0 & pH 7.4 \\
\hline Glutathione & 100.0 & 100.0 \\
L-Cysteine & 10.0 & 59.1 \\
D-Cysteine & 0 & 7.1 \\
$N$-Acetyl-L-cysteine & 6.1 & 8.3 \\
L-Cysteine methylester & 0 & 9.6 \\
Cysteamine & 0 & 3.5 \\
Thiophenol & 5.0 & 10.7 \\
2-Mercaptoethanol & 0 & 2.9 \\
Dithiothreitol & 1.7 & 22.8 \\
D, L-Homocysteine & 0 & 0 \\
L-Penicillamine & 0 & 0 \\
D-Penicillamine & 0 & 0 \\
Coenzyme A & 0 & 0 \\
Thiomalic acid & 0 & 0 \\
Thiosalicylic acid & 0 & 0 \\
Methyl mercaptan & 0 & 0 \\
2-Mercaptobenzimidazole & 0 & 0 \\
6-Mercaptopurine & 0 & 0 \\
\hline
\end{tabular}

duced RNase A as a substrate. The reductively denatured RNase A was spontaneously oxidized with recovery of its enzyme activity at $\mathrm{pH}$ 7.4. This slow spontaneous renaturation could not be shortened by addition of GSH oxidase as shown in Fig. 6. Furthermore, reoxidation with use of both higher concentrations of the oxidase (15 units $/ \mathrm{ml}$ ) and the substrate reduced RNase A $(1.5 \mathrm{mg} / \mathrm{ml})$ proceeded little faster than the spontaneous oxidation (data not shown). Therefore, the oxidase does not show a measurabl activity against free sulfhy- dryl groups in protein.

\section{Effect of $p H$}

The $\mathrm{pH}$ dependence of the enzyme activity was determined with GSH as a substrate in various buffers (Fig. 7). The enzyme showed maximum reactivity in the $\mathrm{pH}$ range from 7.0 to 7.8 . The reaction rate declined markedly both below $\mathrm{pH} 6.2$ and above $\mathrm{pH}$ 8.8. The enzyme activity was not significantly influenced by the kind of buffer used.

\section{Stability}

The enzyme can be stored at $-20^{\circ} \mathrm{C}$ in $0.1 \mathrm{M}$ potassium phosphate buffer, $\mathrm{pH} 7.4$, for at least 6 months with little loss of activity. It was stable at $45^{\circ} \mathrm{C}$ for $30 \mathrm{~min}$ in the $\mathrm{pH}$ range from 5.2 to 8.6. When the enzyme was heated in

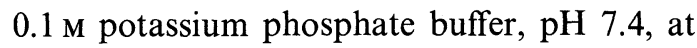
various temperatures up to $55^{\circ} \mathrm{C}$ for $30 \mathrm{~min}$, the remaining activity was $100 \%$ of the original activity.

\section{Kinetics}

From a double reciprocal plot of the relationship between reaction velocity and substrate concentration, the following Michaelis constants were obtained: $0.69 \mathrm{~mm}$ for $\mathrm{GSH}$, $3.6 \mathrm{~mm}$ for L-cysteine and $6.7 \mathrm{~mm}$ for dithiothreitol.

\section{Isoelectric point}

The isoelectric point of the GSH oxidase was estimated to be $\mathrm{pH} 4.2$ by isoelectric 


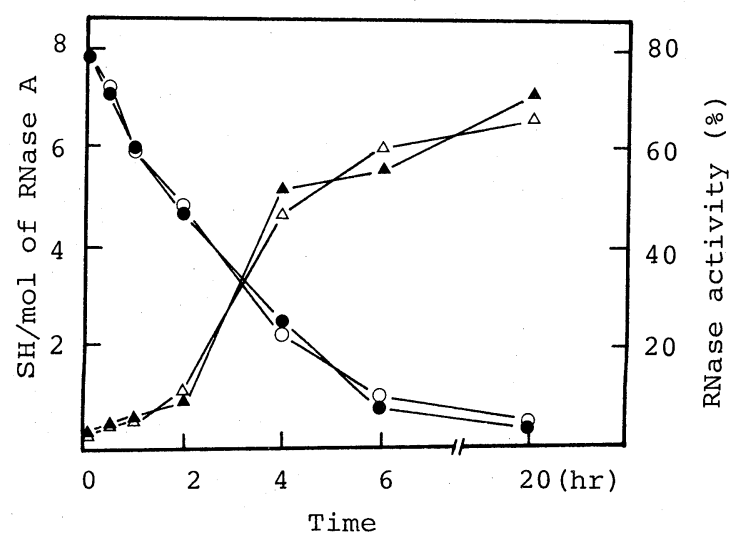

FIG. 6. Reoxidation of Reductively Denatured RNase A.

Conditions are described in Materials AND METHODS: free sulfhydryl group in the absence $(\bigcirc)$ and presence ( $)$ of GSH oxidase; ribonuclease activity in the absence $(\triangle)$ and presence $(\boldsymbol{\Delta})$ of the oxidase. The ribonuclease activity is expressed as a percentage of that obtained with an equivalent amount of undenatured RNase A.

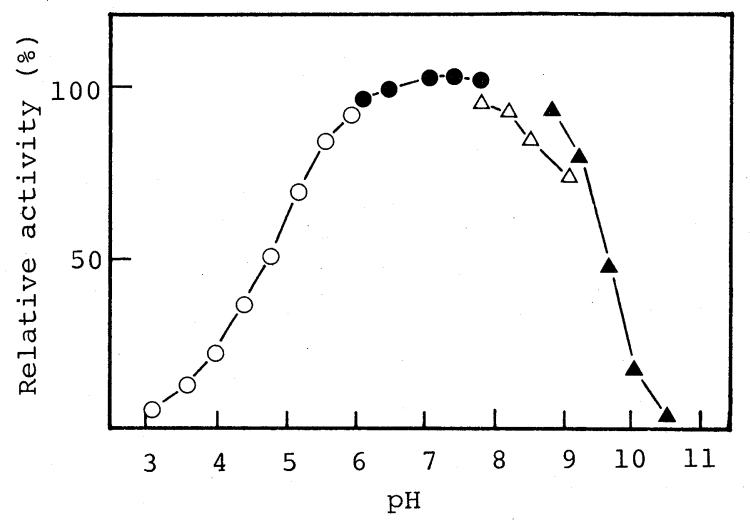

FIG. 7. Effect of $\mathrm{pH}$ on GSH Oxidase Activity.

The enzyme activity was measured in the following buffers: $\bigcirc$, acetate; $\boldsymbol{O}$, potassium phosphate; $\triangle$, Tris$\mathrm{HCl} ; \boldsymbol{\Delta}$, glycine-KCl-NaOH.

focusing.

\section{Inhibitors}

Various compounds were tested for their inhibitory effects on the activity (Table V). The enzyme activity was completely inhibited by $1 \mathrm{~mm} \mathrm{ZnSO}_{4}$. The oxidase was not inhibited by other compounds including EDTA.

\section{DISCUSSION}

We previously isolated a macromolecular antitumor substance and then identified it as a new flavoprotein enzyme, L-lysine $\alpha$-oxidase. ${ }^{16,17)}$ This finding led us to search for other new oxidases produced extracellularly in wheat bran cultures of molds. We have prepared ammonium sulfate precipitatedpreparations from aqueous extracts of molds grown on wheat bran and tested their oxygen consuming activity against arbitrary substrate mixtures such as the one consisting of 23 kinds of amino acids. We have now found and purified a new flavoprotein enzyme, GSH oxidase, from a mold belonging to the genus Penicillium. 
TABLE V. EFFECT OF INHIBITORS ON GSH OXIDASE ACTIVITY

The concentration of the reagents was $1 \mathrm{~mm}$.

\begin{tabular}{lc} 
Reagents & $\begin{array}{c}\text { Rel. activity } \\
(\%)\end{array}$ \\
None & 100.0 \\
EDTA & \\
$\mathrm{KCN}$ & 102.5 \\
$\mathrm{CaCl}_{2}$ & 98.8 \\
$\mathrm{NiCl}_{2}$ & 103.1 \\
$\mathrm{FeCl}_{2}$ & 98.1 \\
$\mathrm{AlCl}_{2}$ & 101.2 \\
$\mathrm{StCl}_{2}$ & 103.7 \\
$\mathrm{BaCl}_{2}$ & 98.8 \\
$\mathrm{MgSO}_{4}$ & 99.4 \\
$\mathrm{ZnSO}_{4}$ & 99.4 \\
$\mathrm{MnSO}_{4}$ & 0 \\
$\mathrm{CuSO}_{4}$ & 80.2 \\
$\mathrm{LiSO}_{4}$ & 92.6 \\
$\mathrm{KCl}$ & 99.4 \\
$\mathrm{KI}$ & 98.2 \\
\hline
\end{tabular}

a Ethylenediaminetetraacetate.

The oxidase was characterized by its great reactivity for GSH and its low one for reductively denatured RNase A. In addition to GSH, several other sulfhydryl compounds such as L-cysteine, dithiothreitol, thiophenol, cysteamine, 2-mercaptoethanol and L-cysteine analogs were oxidized by the enzyme. DCysteine was also oxidized to a lesser extent. This indicates that the oxidase does not have a strict specificity for the L-enantiomer configuration. Most of the substrates except thiophenol, D-cysteine and $N$-acetyl-L-cysteine increased in reactivity at alkaline $\mathrm{pH}$ (data not shown). At acidic $\mathrm{pH}$, the specificity of the enzyme for GSH was considerably enhanced. The oxidase almost exclusively oxidized GSH at $\mathrm{pH}$ 5.0. These $\mathrm{pH}$ effects may be due to the dissociation change of the functional groups near the active center of the enzyme by which susceptibility of the substrates to the enzyme is affected.

It has been well known that the wheat bran culture of molds is efficient for the extracellular production of many kinds of hydrolases. However, no search for novel oxidases characteristically produced in the solid culture has been carried out. Our findings of GSH oxidase and L-lysine $\alpha$-oxidase indicate that the solid culture of molds should be worthy of consideration in regard to extracellular production of unique oxidases. GSH oxidase is also produced in the liquid culture with reciprocal shaking, but the production is much lower than that in the wheat bran culture. This is compatible with the production of L-lysine $\alpha$ oxidase. ${ }^{18)}$ Recently, Campbell and his colleagues reported that three secondary metabolites of the penicillia were formed only in solid cultures that possessed an aerial mycelium. ${ }^{19 \sim 21)}$ They also pointed out the following aspects: (1) in nature, organisms such as the penicillia and aspergilli grow on solid or semisolid substrates; (2) the natural environment of vegetative and aerial mycelia differs markedly as must their physiologies; (3) such environmental differences can be maintained satisfactorily in solid cultures but not in submerged liquid cultures. The efficient extracellular production of GSH oxidase in wheat bran cultures may be correlated with these aspects, though the physiological role of the enzyme is still a mystery.

Acknowledgment. We wish to express our thanks to Professor K. Soda, Institute for Chemical Research, Kyoto University, for his helpful advice.

\section{REFERENCES}

1) V. G. Janolino and H. E. Swaisgood, J. Biol. Chem., 250, 2532 (1975).

2) M. C. Ostrowski and W. S. Kistler, Biochemistry, 19, 2639 (1980).

3) K. Takamori, J. M. Thorpe and L. A. Goldsmith, Biochim. Biophys. Acta, 615, 309 (1980).

4) S. R. Ames and C. A. Elvehjem, J. Biol. Chem., 159, 549 (1945).

5) D. P. Jones, P. Moldeus, A. H. Stead, K. Ormstad, H. Jornwall and S. Orrenius, J. Biol. Chem., 254, 2787 (1979).

6) S. S. Tate, E. M. Grau and A. Meister, Proc. Natl. Acad. Sci. U.S.A., 76, 2715 (1979).

7) O. W. Griffith and S. S. Tate, J. Biol. Chem., 255, 5011 (1980).

8) O. H. Lowry, N. J. Rosebrough, A. L. Farr and R. J. Randall, J. Biol. Chem., 193, 265 (1951).

9) P. Andrews, Biochem. J., 91, 222 (1964). 
10) K. Weber and M. Osborn, J. Biol. Chem., 244, 4406 (1969).

11) E. Haber and C. B. Anfinsen, J. Biol. Chem., 237, 1839 (1962).

12) G. L. Ellman, Arch. Biochem. Biophys., 32, 70 (1959).

13) M. Fujimoto, A. Kuninaka and H. Yoshino, Agric. Biol. Chem., 38, 777 (1974).

14) P. Righetti and J. W. Drysdale, Biochim. Biophys. Acta, 236, 17 (1971).

15) P. J. Hissin and R. Hilf, Anal. Biochem., 74, 214 (1976).

16) H. Kusakabe, K. Kodama, H. Machida, $Y$. Midorikawa, A. Kuninaka, H. Misono and K. Soda, Agric. Biol. Chem., 43, 337 (1979).
17) H. Kusakabe, K. Kodama, A. Kuninaka, H. Yoshino, H. Misono and K. Soda, J. Biol. Chem., 255, 976 (1980).

18) H. Kusakabe, K. Kodama, A. Kuninaka, H. Yoshino and K. Soda, Agric. Biol. Chem., 43, 2531 (1979).

19) C. D. Bartman, D. L. Doerfler, B. A. Bird, A. T. Remaley, J. N. Peace and I. M. Campbell, Appl. Environ. Microbiol., 41, 729 (1981).

20) J. N. Peace, C. D. Bartman, D. L. Doerfler and I. M. Campbell, Appl. Environ. Microbiol., 41, 1407 (1981).

21) B. A. Bird, A. T. Remaley and I. M. Campbell, Appl. Environ. Microbiol., 42, 521 (1981). 